\title{
Spanish Anarchist Engagements in Electoralism: From Street to Party Politics
}

Vicente Ordóñez, Ramón A. Feenstra and Benjamin Franks

\begin{abstract}
Since the 15M movement appeared in 2011, there has been a high level of political participation and experimentation within anti-systematic Spanish activism. The political repertoire has constantly been re-evaluated, with methods constantly revised and evolving, from the occupation of public spaces to the recent creation of new political parties. One of the key aspects of these tactical revisions has been the involvement of anarchist actors in an experimental process of engagement in the constitutional process. Our study identifies the motivations and theoretical justifications that have led libertarian activists to recently take the institutional (electoral) path. This paper stands in the small but growing tradition of works that examine this recent phenomenon of anarchist-inspired constitutionalism, but uniquely concentrates on a detailed case study of the anarchist actors linked to the platform Castelló en Moviment (CsM). As a result it explores that complex and disputed relationships and motivations that operate within $15 \mathrm{M}$. It thus describes the anarchist influence in recent electoral developments, and identifies proponents justification for engaging in these previously rejected methods and highlights some of the doubts raised against this electoral experiment.
\end{abstract}

Key words: anarchism, institutions, activism, political participation, social movement, political parties.

\section{Introduction}

The Spanish political context is going through a time of volatility as far as political participation is concerned (Tormey, 2015a; Postill, 2013; Monterde et at., 2015). Since the $15 \mathrm{M}$ movement appeared in 2011, there has been significant experimentation within civil society, expressed through protest-camp occupations, demonstrations, stopping evictions, citizen platforms proliferating to defend public services and popular legislative initiatives (Marzolf \& Ganuza, 2016). The experiment by grassroots activists 
in 2015 with constitutionalism is an indicator of this wider 'institutional-electoral shift. In this context, there has been a shift from an explicitly anti-electoral protesting, contesting and direct action phase of street politics -"They call it democracy and it's not" (Q. in Galais 2014, p. 338) - to a DiY politics that seeks to operate concurrently with the electoral processes -“we represent ourselves".

This study focuses on the institutionalizing processes of parts of Spanish activism. Initially the tendency is to either regard such institutionalisation in polar terms. From a radical social democratic perspective, it demonstrates the effectiveness of radical social democracy to engage with new challenges (Galais, 2014) or, from the traditional anarchist side, to regard this institutionalisation as part of the decline or crisis of 15M movement (for instance Grupos Anarquistas Coordinados, 2013; Bray, 2017). These tensions persist within the paper, reflecting the perspectives of the authors, the research participants and the wider activist communities they operate within. The aim here however is to try to examine the constitutional turn in the terms of the activists, as a shift towards an experimentation in a new political arena.

There are many striking aspects of this new constitutional phase. First of all, the number of actors involved in the process is substantial and geographically extensive, going beyond Castellón and the Castelló en Moviment (Castellon in Movement) (CsM), with other so-called "municipalist projects" arising throughout the regions. In addition, and covered more extensively in popular and academic literatures, are the national movements that originated in the social movements Podemos (We Can) and Partido X (Party X) (see for instance Kioupkiolis, 2016; Orriols \& Cordero 2016; Rodon \& Hierro, 2016). Secondly, although the "Podemos phenomenon" is well-known internationally, the success of the municipalist platforms have gained relatively little attention although they have won elections, and govern some towns and cities (Barcelona en Comú, Ahora Madrid, Zaragoza en Común or Por Cádiz Sí se puede) or play a determining role in constituting new local governments (CsM, among others). Such electoral impact is especially notable as these platforms were created between 2014 and 2015. Thirdly -and one of the key elements for the present analysis - is the participation of anarchist actors, who have to date been reluctant to take part in representative politics.

A considerable number of grassroots activists participate in CsM, with a high level of political experimentation which, to some extent, challenges the vertical 
structures of conventional political parties. Similarly, despite it recently coming into being - CsM had the first activist gathering in October 2014 - it gained 10,443 votes (13.06\% of the total) in the 2015 local elections held on 24 May in the city of Castellón. ${ }^{1}$ This result gave CsM four councillors. The councillors supported an alternative local administration, to the conservative party, Partido Popular which had governed this city with an absolute majority since $1991 .^{2}$ As such CsM in particular, and the municipalist project in general, differed from other anarchist engagements in electoralism (Bogad, 2005; Author 3, 2015), which were either unconcerned with or outrightly rejected taking elected positions and were principally concerned with using the electoral process to illustrate the weaknesses of representative politics.

This paper objectives are to: 1) Analyse main characteristics of the anarchist actors of CsM and 2) Situate the key challenges that the activists highlighted as being significant for those engaging in constitutionalism and 3) Elucidate and contextualise the advantages that have arisen in engaging with constitutionalism.

Studying the case of CsM provides a pertinent case study for examining the complex innovative political ecosystems that exists in Spain as a result of $15 \mathrm{M}$, and to complement the numerous works on this movement which have focused exclusively on either national movements or large cities - especially Barcelona and Madrid. This study will be useful for theorists of citizenship, exploring its many formulations and manifestations and to anti- and non-state actors who are sensitive to the impacts of prolonged activism in on participants: how it impacts on and transforms their theoretical and practical positions. The standard assumption is that anti-state activism is generative, promoting further prefigurative practices outside and against the state. However this study by focussing on initially anti-state actors and their justification for turning to social democratic methods, initially challenges this traditional anarchist concept. Factors that attract these activists to the institutional path include: 1) it provides new

\footnotetext{
${ }^{1}$ Results available at: http://resultados.elpais.com/elecciones/2015/municipales/17/12/40.html

2 The Castellón City Council is made up of 27 councillors. For the investiture, 14 votes in favour were required. Castelló en Moviment opted to support the investiture of the social-democrat party PSOE (7 councillors) and a regional left-wing party called Compromis (4 councillors). This implied agreeing about a programme for the investiture, but not forming part of the local government. The governing programme can be consulted at:

https://castelloenmoviment.org/wp-content/uploads/2015/06/PROGRAMA-DE-GOVERN-

MUNICIPAL.pdf
} 


\section{Versió pre-print}

openings for political struggle (goal-orientation), and 2) desire for political experimentation (methods).

\section{Methodology}

The methodology is based on a case study of the political motivations, effects and trajectory of the CsM from the wider 15M movement. From a qualitative approach, we aim to identify the influences that grassroots participants identified as factors for the shift from a street movement to a political party. In this respect, the methodology combines two techniques: in-depth interviews held with activists in February 2016 and autoethnographic research based on one of the investigator's experiences in $15 \mathrm{M}$ and CsM to identify key issues and transitionary stages.

Previous research projects studying 15M have used interviews as a key resource. These projects include, Castañeda (2012); Flesher Fominaya (2014); Micó and CaseroRipollés (2014); and Romanos (2016). Unlike most 15M studies our interviews (and centre of interest) are not based on national movements like Podemos or the two major cities Madrid-Barcelona. In this case the interviews (and the topic of study) were held in Castellón (Spain) which like other parts of Spain witnessed extensive 15M agitations. Nine in-depth interviews were conducted with key actors linked to anarchism; five women and four men who belonged to groups like the Plataforma Afectados por la Hipoteca -PAH- (Platform for People Affected by Mortgages), Spanish trade unions like CNT (National Confederation of Labour) and CGT (General Confederation of Labour), and self-managed groups like Casal Popular de Castelló (Popular House of Castellon). Of the nine interviewees, two people currently hold representative posts as councillors, and another activist works for the City Council as an advisor connected to CsM. All the others are politically active in the platform's assembly and in local social movements. The work therefore concentrates on those who engaged in the constitutional experiment, rather than on the anarchist colleagues who remained antipathetic to electoral activism (Bray, 2017).

Consistent with other relevant research on aligned topics such as anti-austerity and pro-democracy movements - such as the 15M Madrid assemblies (Corsín \& Estalella, 2013), the dynamics of Occupy (Graeber, 2011; Graeber, 2013), or on the common elements existing across several European movements (Kaldor \& Selchow, 2013 ) - this research includes autoethnographic research as a complementary element to 
the interviews. One of the researchers has collaborated in building this political project, whilst others were engaged in different levels of involvement (or no involvement at all). Such authorial differences allowed for detailed insights and autoethnographic reflection and perspectives that maintained a critical distance from the analysis object.

\section{Literature review: anarchism facing the institutional path}

In many contemporary western democracies, political parties and party-centric politics are perceived by citizens and theorists as a cause of political disenchantment and democratic disengagement (Crouch, 2004; Hay, 2007; Alonso, 2014; Tormey 2015a;). Right-wing populist politicians and parties, from across Britain and Europe to UKIP who have gained support partly by portraying themselves as a rejection of standard political parties, established within traditional networks of power and corresponding corruption scandals (Fieschi \& Heywood, 2004; Abedi \& Lundberg, 2009). It is a feature too of Donald Trump's appeal to voters in his successful bid for the Republican candidacy. Traditionally anti-politics, for anarchists, is a deeper rejection of existing political party loyalties, as it opposes the hierarchical state and party apparatus.

As Boggs' (1977a-b) distinction between prefigurative politics and structural reformism identifies there has been a clear division between the core anti-political, antihierarchical and radical concepts of anarchism and the statist, reformist and consequentialist concepts of social democracy. The first rejects hierarchical state structures in favour of horizontal, co-operative forms that foreshadow desired future socio-economic arrangements (Proudhon, 1851; Bakunin, 1953; Kropotkin, 1987; Malatesta, 1974; Guérin, 1970; Ward, 1996; Cappelletti, 2006), the latter seeks to achieve egalitarian social change by participating in and slowly reforming state structures (e.g. Bernstein, 1961 III c. and d.; Giddens, 2009). The anarchist rejection of structural reformism can be encapsulated in García Calvo's statement, who stated that it is a fallacy “to think that the Enemy's weapons (the Enemy is inscribed in the very form of its weapons) can be used against the Enemy" (1977, p. 69).

However anarchist strategy is extremely complex and fluid. Because it rejects (an) a determining fixed principle (archē) that legitimates forms of control to achieve a single predetermined goals (telos), this makes it a more adaptable ideology than some of the rigid, highly-structured target driven competitors. It would, however, be mistaken to consider it as lacking an ideological structure of core, stable mutually defining features 
(Freeden, 1996). Anarchism can be defined in terms of a rejection or contestation of hierarchies, such as capitalism, racism, sexism, a social view of freedom in which access to material resources and the liberty of others are prerequisites to personal freedom, and a prefigurative commitment to embodying goals in one's methods (Colson, 2001; Author 3, 2006; Colombo, 2014).

Whilst the anarchism discussed here is largely of, what Graeber (2001) and others (e.g. Kuhn, 2009) refer to as 'small-a', concentrating on the micropolitics of daily practice such as utilising anarchist anti-hierarchical decision making in their daily activities and seeking immediate (albeit partial) solutions, rather than in prioritising grand social change. 'Large-A' anarchists are more consciously part of the anarchist tradition and more overtly geared towards developing large scale anarchist organisations operating on anti-hierarchical, democratic principles to facilitate significant structural change. ${ }^{3}$ The differences between these two tendencies are overplayed. 'Small-a' anarchists are inspired by revolutionary change and large-a anarchists engage in immediate direct action, the differences are largely ones of emphasis and location. In events like $15 \mathrm{M}$ and Occupy, there were great opportunities for putting anarchist forms of organising into effect with participants with no knowledge of anarchist history, little previous familiarity with this way of working and no overt desire to adopt an 'anarchist' label as part of their self-identity. It confirmed small ' $a$ ' anarchists' contention that anarchism can operate without overt anarchists.

Anti-statism is a relatively stable feature of anarchism it is not sufficient to identify it as there are other hierarchical groups, such as propertarians also claim to support this principle. Additionally, there have been minority currents of the anarchist movement, who have defended engagement with the state as providing opportunities for anti-political activism. As well as the guerrilla engagements, largely done for propagandising against the state rather than gaining representation and working through the state (Bogad, 2005; Author 3, 2015), some have sought the institutional path to make socio-political transformations, such as Brousse's revolutionary reformism (Nettlau, 1980), Martínez Prieto's state anarchism (1966) and Murray Bookchin's libertarian municipalism (2015). These regarded structural reform initially as one tactic amongst many as part of an anti-hierarchical strategy, but increasingly becoming the

\footnotetext{
${ }^{3}$ Anarchism has traditionally derived from with working class, socialist and labour movements.
} 


\section{Versió pre-print}

dominant and overriding strategy marginalising prefigurative politics. Because these constitutional variations apparent connive with hierarchical power and rejects prefigurative anti-politics in favour of social democratic tactics, it has led to significant criticism from more consistent anarchist theorists and groups (Bakunin, 1984; Goldman, 1969; Clark, 2013; Anarchist Federation, 2014; Dickens, 2015).

Given this background, the decision by anarchist CsM members to opt for constitutional engagement is particularly worthy of attention, given its marginal and often antagonistic position within anarchism. It seems particularly incongruous given that the CsM's institutional turn comes about in a political context of greater antipolitical activism. Since 2011, widespread, large demonstrations took place that were marked by the adoption of direct action tactics. These have included blocking Parliament, occupying bank branches, acts of civil disobedience against state and business authorities and sit-ins. The slogans that marked the initial period of Spanish, popular anti-political activism included the adoption of the avowedly anti-constitutional slogan: "don't vote for any of them" (Galais, 2014, p. 346). So what are the causes, objectives and difficulties hidden behind anarchist actors' participation in electoral platforms as of 2014-15?

\section{Castelló en Moviment: origins and main features}

The different municipalist strategies launched in Spain between 2014 and 2015 radiated out of the original project Guanyem Barcelona (Let's Win Barcelona, now called Barcelona en Comú). Guanyem (Let's win) was the original name of this initiative and was shared by all the other municipalist platforms in Spain, but was dropped due to legal registration reasons. Some platforms adopted "en comú" ("in common"), while others like Ahora Madrid, Castellón en Moviment, Marea opted for other names. ${ }^{4}$ The initial drivers of Guanyem were people from 15M, social movements, academia and neighbourhood associations. The public face of Guanyem Barcelona was the charismatic Ada Colau, who was the former spokesperson of the PAH. The Guanyem Platform explicitly encouraged "taking back the institutions and put them at the service of the majority and of the common good", and linked this strategy with grassroots movements. It claimed the "need to strengthen, more than ever, the social fabric and

\footnotetext{
${ }^{4}$ http://www.eldiario.es/catalunya/politica/Guanyem-Barcelona-presentara-concurriraelecciones_0_354865337.html
} 
spaces for citizens to self-organise". 5 Guanyem's call inspired many of the cities that sought to consolidate a new party model with a marked innovative spirit (similarly to $15 \mathrm{M})$, arranged into principles of participation, horizontality and ethical commitment, and with a political programme based on anti-austerity and support to the most underprivileged (Author 3, 2015).

The sudden appearance of Guanyem Barcelona also inspired activists from the city of Castellón to launch its own municipalist platform. Not having a publicly known and charismatic leader like Ada Colau in Barcelona, and the fact that the local social movements and activists (activists from self-governed social centres, PAH, ecologists groups) were poorly linked, made the beginnings of such a platform quite hesitant. Indeed it was not until 24 October 2014 that the first public assembly took place. It was here that the platform, and its organisational principles and basic policies, were publicly debated, having been initially proposed in activist circles six months earlier. ${ }^{6}$ In 2011 the decision to launch an electoral project of activists based on building a new representative political model split the wider $15 \mathrm{M}$ activist community. A large number of members distanced themselves, and opposed, the electoral path. Nonetheless in 2014, there was a larger number who supported the electoral turn and given impetus by Guanyem Barcelona when CsM began to develop. Its characteristics were: i) plurality of actors, ii) pragmatic solidarity based on a small number of shared values (a minimum) and iii) promoting and using a new way of doing politics

\section{Plurality of the actors involved}

Some two hundred people have contributed to and have been present in building the platform. However, the active group of actors (as the constant number of people in assemblies evidences) is made up of core of about 80 people. ${ }^{7}$ They are spread out in different groups, mainly made up of members of the $P A H$, Spanish trade unions like the CGT, self-governed social centres like Casal Popular de Castellón, Platforma Petroli

\footnotetext{
${ }^{5}$ See: https://guanyembarcelona.cat/lets-win-barcelona/

${ }^{6}$ On 21 April a brief informative press release was published in the local newspaper Levante EMV. As of 24 April, information was progressively supplied about the launching of a new municipalist platform. See:

http://www.levante-emv.com/castello/2014/10/21/dignitat-22-m-debate-creacion/1177161.html

7 This number was obtained from the public minutes of the CsM platform from February-May 2015 (a key time of the platform's consolidation). Information available at: 
No - Columbretes Netes (Group against oil platform), new political parties similar to 15M like Podemos (biggest group) or Partido $X$ (small group). It also includes Izquierda Unida party members (United Left, former Communist Party), independent members and green party supporters.

\section{Pragmatic solidarities}

Although all the groups that make up CsM come from a broad left-wing section of the ideological spectrum, there are significant ideological and historical differences between them. In order to provide a basis for collegial and effective operations, historical differences and ideological disputes were deliberately left to one side, and instead the concentration was on finding shared activities and policies which were agreeable to all the main groupings, even if they agreed to them for different reasons. By sharing in participatory and prefigurative practices, shared values develop.

The 15M identity had already helped to unite different groups (Monterde et. al, 2015) because of common concerns at the socio-economic and political impacts of the Spanish and European government's domestic and economic. 15M's concentration was on practical, direct and radical responses to socio-economic policies and problems and the political institutions and people who were imposing them. Following 15M, CsM prioritised the prevention of evictions and opposing cuts in social provision. In the political sphere, it continued the fight against corruption and implementing transparency mechanisms (by having a public disclosure of an a limit on council expenses) and promoting a more participative democracy by bringing in revocation mechanisms (recall and deselection). CsM members placed their trust in not only the problemsolving capacity of assemblies, but also in the available digital tools that can empower citizens. Using Information and Communications Technologies (ICT), ensures wider access to, and scrutiny of, policy decisions and discussions.

\section{A new way of "doing politics"}

In line with this idea of participative democracy and the wider engagement through ICT, various CsM members show a strong commitment to anti-elitism, embodied in their rejection of conventional parties. This rejection of conventional party structures is reflected in a series of internal mechanisms that define CSM's structures: 


\section{Versió pre-print}

- The assembly as a supreme body of the platform. ${ }^{8}$

- A strict ethical code that limits salaries, terms of office and responsibilities. ${ }^{9}$

- Revocation mechanisms that help maintain strict control of councillors voted by the assembly.

- Participative and open mechanisms for selecting candidates. ${ }^{10}$

- Rotating positions of responsibility in the platform.

- Devising collaborative programmes by means of digital tools and attending assemblies.

- Rejecting financing from banks in order to preserve its independence.

- Electoral campaign based on direct contacts with citizens and use of social media.

These features distinguish CsM from conventional parties and the vertical structures that characterise them. To an extent, CsM can be defined as a "connective party" marked by a decentralised structure where participating actors are not subjected to imposed orders or decisions. Actors cooperate together, not because they defend a fixed pre-given and universal ideological framework, but because they share a project and a style of "doing politics".

\section{Characterising the anarchist actors of CsM}

The activists who were interviewed identified themselves as having flexible approach to tactics and organisation. The best way to capture the ideological character of agents involved in developing the institutional path is to consider them as actors with an anarchist training or background. This is because the interviewed actors either selfidentify as heterodox anarchists, libertarian activists, or are simply members of autonomous groups. One activist observed: "I consider myself to be one of these anarchists who have been rejected by orthodoxy" (Activist no. 2). All of them came from cultural centres, libertarian groups or movements, or are members of anarchist trade unions, and they acknowledge that anarchist ethics, its claims and struggles, form

\footnotetext{
${ }^{8}$ The Assembly Regulations are described at: https://castelloenmoviment.org/wpcontent/uploads/2015/09/Reglament.pdf

9 The Ethical Code is available at: https://castelloenmoviment.org/codi-etic/

10 The most important documents on this matter can be consulted at: https://castelloenmoviment.org/documents/
} 


\section{Versió pre-print}

part of a political culture that cannot be left to one side. Indeed one of the interviewed activists pointed out:

I don't see my participation in CsM as if I were an anarchist activist, but as a series of political practices that include libertarian values: rejecting hierarchy, horizontality, anti-authoritarianism or questioning the idea about delegation and representation. This is the libertarian legacy that I defend from CsM (Activist No. 1).

Using a similar line of argument, another activist stressed the importance of anarchist ethos; i.e.: the values embodied by the anarchist tradition, rather than the ideological title as being the most decisive factor for her activism.

I don't know the name of this movement. All I know is that values and actions are important. If we have to disobey, then so be it. If we have to take a risk and they handcuff us, then we take it. If justice goes one way and social justice goes another way, then I don't care about justice. What's important is solidarity, empathy, mutual aid, determination or cooperation (Activist No. 3).

Nonetheless, using libertarian-type political tools in institutions can be a problem for several reasons: is it possible to combine self-management, direct democracy and anti-representational politics, with institutional praxis: verticality, leadership or representation? If activists propose operating within existing, usually despised, institutions, how could this be explained and legitimised to people who have opposed to any form of institutional collaboration? We cite the two main reasons why these activists consider the institutional path to be valid in political terms: 1) it provides new openings for political struggle; and 2) desire for political experimentation.

\section{New openings for political struggle}

During our interviews, the CsM activists trained from anarchism indicated that one of the main reasons that led them to consider experimenting with other political logics had to do with promoting political struggle, especially around issues of social justice. One activist explained:

When the economic crisis began about 2008, we at the CNT wondered: "how can we fight from anarchism against social injustice?". Then PAH appeared. 
PAH was made up of many impoverished people who went to it because it was the only group that tried to solve their problems. If there were other alternatives, they would have had to choose. But there was nothing else at that time (Activist No. 1).

The interviewees from CsM, who all had extensive engagement with anarchism, pointed to the importance of the housing and social struggles carried out by PAH in particular, and the $15 \mathrm{M}$ movement as a whole, as providing a turning point in their political paths in their reconsideration of political strategy. As one explained:

We wanted to influence the city's political life, but then $15 \mathrm{M}$ came along. $15 \mathrm{M}$ allowed us to learn to work with other people we did not know, and it made us enter dialogue and negotiate because there were so many political sensitivities (Activist No. 5).

The activists admitted that $15 \mathrm{M}$ made exercising politics possible in the immediate lived experiences of everyday life. Anti-hierarchical activism operated through the micropolitics of ordinary activities, in the new forms of autonomously-organised protest and participatory decision-making that intersected with each other. Many actions and attitudes that stemmed from $15 \mathrm{M}$ in 2011 were for many people the unmistakable proof of the movement's libertarian origin. About this particular point, one of the interviewees stated: "I have spoken with anarchists who found in $15 \mathrm{M}$ what they had been waiting for, for many years: assemblies held in town squares, people occupying public spaces, civil disobedience, blocking Parliament, etc.” (Activist No. 7).

The fact that one section of the wider $15 \mathrm{M}$ opted, especially since 2014 , to redirect protests into creating political parties, provided the impetus for these activists' politics to also turn decisively towards the institutional path. This was how an activist expressed it: "after 15M, I thought that constitutionalism was a hypothesis that had to be experimented with" (Activist No. 1). It was after the 15M demonstrations that these radical activists saw representative institutions as a way to not only to continue to fight against social injustices, but above all, a way to coordinate collective actions that would have a short-term positive impacts for the disadvantaged and oppressed sectors of the population, without negatively impacting on existing anti-political organisations or tactics. 


\section{The desire for political experimentation}

In recent decades, political experimentation in western democracies has been stressed as one of the most relevant characteristics of social movements (Juris, 2008; Estalella \& Corsín, 2013; Flesher Fominaya, 2014b). There is an important inter-relation between participatory democracy and experimentation, and not only in epistemic terms, but also, and above all, in methodological terms (Dewey, 1954; Ansell, 2012). Anarchism largely rejects positivism and universal forms of knowledge (see for instance Bakunin, 1972; Malatesta, 1984). It considers that individual and collectives have a significant role in generating forms of knowledge that are contextual and practice-based. As such, there is a general rejection of dogmas and a willingness to innovate, test and re-evaluate social activities and political methods. Some theorists within the field of anarchist studies, have explored the connection between experimentation, direct democracy and commitment to anti-hierarchical autonomous co-operation (Collier \& Lowery, 2005; Graeber, 2009; Razsa \& Kurnik, 2012).

Many of the anarchist activists within the CsM extended this experimentation further examining political logics that have previously had been marginal or excluded from anarchism. Use of representatives, rather than rely on consensus or direct democracy, reducing core principles to more pragmatic and minimal concerns in order to extend links of solidarity and greater engagement with the mass media. These moves were motivated, by a feeling of dissatisfaction of the constraints to existing antihierarchical anarchist methods, which lead to inertia. One activist said:

We have been bearing the flag of anarchism for decades, but it does not work for me. So some of us have decided to explore other forms of political experimentation, like the institutional kind. Perhaps this alternative can be understood as 'possibilistic', but certainly it is clear that doing things as usual do not lead to any political change (Activist No. 2).

Embracing methods more consistent with social democratic movements, was regarded by interviewees as an adventurous experiment in extending the repertoire of different and varied collective actions, with anarchists who rejected constitutionalism pejoratively portrayed as favouring inactivity. One of the activists referred to the political praxis that developed in the 1990s and at the beginning of the $21^{\text {st }}$ century, and 


\section{Versió pre-print}

they compared it with actions currently being performed: "previously political experimentation was extremely limited. We followed a classic strategy: demonstrations, posters, graffiti. Now we move out on to streets, in districts, and we have been able to create citizen action networks" (Activist No. 4). The activists seem to be contrasting constitutionalism with a very limited array of political gestures - largely symbolic rather than the social and immediate direct action of $15 \mathrm{M}$ and other forms of practical prefiguration associated with intense anarchist mobilisation. It maybe the decline in opportunities for actual direct action, like occupation, bailiff-resistance and industrial action, rather than regarding these actions as inert, that made constitutional action seem preferable to largely symbolic protest.

Experimentation and extending the repertoire of these activists' collective actions was seen as a way of going beyond the theoretical-practical commitment to prefigurative, anti-hierarchical methods and the security of staying within the standard repertoire of tactics approved by anarchist activists. The desire to promote a change in the game rules of local politics, and the possibility of influencing the life of fellow citizens, have led them to reassess their political culture and to pose questions about the limitations of anarchist praxis. As one activist explained:

When I self-criticised myself from the anarchism perspective, I considered: "what have we done to win in political terms? What can we do from now on?". When I talk with anarchist friends, they tell me that they prefer to remain in the ghetto rather than to start with contradictions. I think that this is a mistake: let's start with contradictions! (Activist No. 1).

From these statements, we can deduce that the most decisive point for these activists is that they identify opposing positions with maintenance of a certain ideological purity, whilst experimenting with institutionalism is regarded as a pragmatic and creative position. However, the wish to experiment is consistent with anarchist epistemologies and is a product of the activists' engagement in anarchist practice, even if this particular form appears to be an outlier. Anarchism activism and autonomous education gives a central position to, and tries to provide a harmonious environment for, self-critique. It seeks to promote regular reflection upon, and analysis of, the assumptions that underlie individual and group activity and to produce innovative changes in anarchist practice 


\section{Versió pre-print}

(Jeppesen, 2010; Ibáñez, 2011). Similarly such reflection should also be applied to this electoral turn, to see if the electoral experiment supports the criticality and wider ethos of solidarity that prompted it.

\section{Difficulties with the institutional path}

From the interviews conducted with the nine CsM activists from an anarchist background, the most significant initial problem they faced when opting for the institutional path was that they were committing themselves to forms of politics and social relations they were still suspicious of and had been previously hostile to. They faced the dilemma of generating alternative anti-hierarchical forms of struggle but in doing so, must generate sufficient support to initiate and sustain them. Here the dilemma involves advocating direct (anti-representational) forms of politics whilst engaging in representational politics in order to promote them. The activists were concerned that following the constitutional path would undermine rather than support anti-hierarchical methods. One activist expressed it as follows: "Our challenge is to see through our work how we can overthrow the idea of representation or if, in the long term, we end up reinforcing the idea of delegation" (Activist 7). Another activist expressed these very same doubts when she wondered: "in the end, will we achieve citizen empowerment or will we once again become some sort of recycled version of the old type that never gets any further?" (Activist No. 5) Consistent with the idea of the constitutional turn being an 'experiment' activists were acknowledging the real possibility of it being a failure.

This problem of constitutionalism for anarchist activists is that it develops a political hierarchy between representatives and the represented. It creates uneven power-structures and social practices to maintain this hierarchy, leading to the development of a separate political class with interests distinct from those communities the representatives initially came from (Bakunin, 1984, pp. 58-60). One activist explains this problem using a musical analogy:

The challenge is to build something organic, which is very complicated. For instance in rhythm terms, inside-outside are two worlds. The people working from the inside of institutions have different rhythms, which are neither better nor worse than those who work from the outside. In any case, what I mean is that participation in institutions has opened up possibilities to do the things that 
we wanted to do before and didn't know how to. Now we have an infrastructure that lets them to listen to us (Activist No. 4).

Activists 4's comments are particularly revealing. It highlights activists recognition of the different ways of operating between the institutional and non-constitutional structures, but considers initially that neither is preferable. It ends, however, by identifying an 'us' and 'them' and the need to develop an 'infrastructure' to ensure that the representatives from the movement ('them') still 'listen' to the 'us' (the activist base of CsM). The two structures do not generate a natural harmony, but require conscious manipulation to prevent one rhythm overriding the other. The use of 'us' and 'them' is indicative of the impact of the hierarchy of representation on the previously antihierarchical social movement, one which has reduced the role of the 'us' to speaking, whilst it is the representatives who will act on their behalf.

The activists also discussed an additional problem concerning the erosion of the anarchist ethos. Would engaging with constitutionalism undermine the values that sustain radical, co-operative activities? Some activists maintain that their current electoral commitments preserve their values: "my values have not changed a bit: I am still a feminist, a left-winger and a libertarian" (Activist No. 5). Nonetheless, other activists stress the difficulties that they must face when working from two apparently antithetical perspectives: "the hard thing is to maintain authenticity and commitment when it is so easy to fall to falseness and cynicism" (Activist No. 8).

Despite these difficulties and challenges that the CsM anarchist actors face, who support politically experimentation with institutional politics, we realised that they wish to fulfil two basic objectives: 1) consolidate participative municipalism and 2) create a critical mass to support anti-hierarchical activities.

\section{Advantages of the institutional path}

Municipalism is the term CsM activists use to describe the transformation of local governments into direct democracies. They argue that true democracy only occurs in a self-managed, participative assembly, with direct democracy, rather than the managerial, representative model of standard local government. One activist states "I believe that the political tool that justifies choosing between the institutional or constitutional path, call it what you will, is municipalism" (Activist No. 6). Bookchin 
(1995; 2015; Bookchin \& Biehl, 2009) and his followers have been the keenest defenders of municipalist tradition within anarchism anarchism. There are important precursors in, for instance, Proudhon's federalism (2011) and in Balius's free municipality (Amorós, 2003). Others like the Provos and Kaboteurs' engaged in municipal electoralism for conflicting reasons, for some it was a way of destabilising an institutional of centralised power to promote direct, counter-cultural practices for other participants the municipal structure was capable of reform and could be used for supporting radical activities (van Duijn, 1972; Bogad, 2005; Observatorio Metropolitano, 2014). CsM activists of anarchist origin are supporting this latter version of municipalism: "we want an assembly-based and horizontal City Council that provides the means so that citizens can direct their own affairs" (Activist No. 8).

CsM activists have managed to introduce major changes into the way the Castellón City Council operates. One of the activists told us, for example, that they have enabled platforms like PAH to be on the municipal work tables that deal with housing problems without having to revoke their activist repertoire:

In December 2015 we occupied a building that housed six families. In less than a month, the City Council contacted Bankia [a financial institution financially supported by the Spanish government intervention in May 2012]. The occupation has forced the authorities to take measures. During the meetings we have had with the City Council's Social Services, we are forcing policies to be made to allow access of the people who genuinely need social services (Activist No. 3).

In relation to this transformative conception of municipalism, another activist highlighted one of the proposals that CsM is developing to amend the Castellón City County regulations: "we are working on a document that will shortly be approved and will allow neighbour associations and groups to be able to directly present their demands without having to use political parties as go-betweens" (Activist No. 9). Another activist stated:

For two months we have been trying to hold an open assembly with citizens so they can ask questions or make proposals. OK, perhaps it is being interpreted as a symbolic gesture: but it is what is symbolic that generates a political reality (Activist No. 6). 
With their statements, we deduce that these activists wish to change traditional mechanisms of political intermediation to create channels of citizen participation and direct influence in a municipalism transformation model.

Moreover, the activists we interviewed pointed out the importance of consolidating a form of counter-power exercised by a mass networked of interlinked groups. The activists, thus, consider this municipalist model to be different from the liberal representative model, as for them the representative democracy transforms citizens into a passive mass that transfers and cedes its power to a governing class. It also damages the citizenry's development of critical skills. "We do not want passive voters or citizens. We want people who get involved in the city's problems", said one of the activists (Activist No. 7). As a result all the participants were in agreement about the importance of developing sites and practices in which citizens develop analytic and evaluative skills. Participatory democratic fora, they argue, encourage reflection and dialogue. Radical decision-making practices encourage rational participation and free expression. It is the development of these skills to enhance anti-hierarchical social practice that was important. The institutional experiment was undertaken to achieve these goals and would provide the basis by which success would be judged.

\section{Conclusions}

CsM is a small, but innovative, part of the broad activist ecosystem which developed in Spain in the aftermath of $15 \mathrm{M}$. In this context, anti-austerity initiatives have made it possible to consolidate a type of democratic laboratory where political considerations, as well as tactics and repertoires, are constantly being redefined by those who lead them. Creativity, political pragmatism, experimentation and openness have become principles that define the action taken by activists.

$15 \mathrm{M}$ was a convergence process of groups and identities. This movement has persisted albeit forming into heterogeneous political initiatives that range from civil disobedience to the recent creation of new political parties. As a result of its electoral turn, some of the anarchist actors involved in the movement have altered the way they view political strategy and representative institutions. The former anti-political positions, once core tenets for former generations of anarchist activists, were entirely absent in our conversations with the CsM activists with anarchist backgrounds. In part 
this change in the anti-electoral positions reflects a greater fluidity in other aspects of the activist identify. There was a similar absence of precision in terms of universal remedies or formulae to improve the political situation. Their position comes closer to what Francois Lyotard called "pagans" (1984). Their political affiliation is not sustained by strict adherence to particular organisation, tactics or identities (Tormey, 2015a; 2015 b), but by a primary opposition to a political system that generates injustice and inequality.

It is this fluid politics of opposition that led them to extend their political repertoire, and to even be inclined to a dynamic - the institutional engagement - that lie outside of, and in opposition to, their previous strategies. Their desire to struggle against what they consider to be social injustices, along with a wider change within $15 \mathrm{M}$ to embrace constitutionalism, provided the impetus for engaging in representative politics. Just as politics in Spain was extending beyond its traditional arenas of attention - the state and representative institutions - towards autonomous action, anti-state actors returned to this terrain. Nevertheless, they adopted this stratagem because they viewed the corruption that had motivated the rise of $15 \mathrm{M}$ as providing an opening for social activists to engage with and alter municipal institutions. It was not seen as renouncing the horizontal spirit, values or the typical dynamics of anarchism, but an experiment in taking them into new directions. The objective of the activists we interviewed is to transfer their (anti-)political experiences and tactics to the spaces linked to transform the performance of representation and alter the relations of hierarchical power found in Town and City councils. A move that is not altogether inconsistent with some minority traditions within anarchism, such the libertarian municipalism of Bookchin or the Kaboteur phenomenon (van Dujin, 1972). They argued that a policy built on direct democratic institutions could create more organic and radical forms of citizen participation (van Duijn, 1972; Bookchin, 2015).

Such considerations leave some open questions for the future: will the anarchist CsM be successful in transforming municipal councils into networks of direct democracy or will they remain institutions predicated on the hierarchy of the representative-represented? Will such engagement in Town and City Councils have positive material impacts, extending the autonomy of citizens or stabilise capitalist economies? How will the identities of activists alter as a result of such engagement? Will values subtly shift away from commitments to social solidarity, self-management 
and criticality to paternalistic managerialism, liberalism and electoralism? Will activists still consider the constitutional turn to be an experiment, or will it become a strategic dogma, with its success criteria framed by the principles of liberal democracy.

The CsM experiment might not be one isolated to Spanish politics. Some cases of electoral participation by activists with anarchist identities have been practised by Red Libertaria in Chile (2013) and Class War in Great Britain (2015). If this is a potentially new trend in $21^{\text {st }}$-century anarchism, then it is one with significant risks as well as possibilities.

\section{References}

Abedi, A. \& Lundberg, T.C (2009). Doomed to failure? UKIP and the organisational challenges facing right-wing populist anti-political establishment parties. Parliamentary Affairs, 62(1),72-87.

Alonso, S. (2014). Votas pero no eliges: la democracia y la crisis de la deuda soberana en la eurozona. Recerca. Revista de Pensament i Anàlisi, 15, 21-53.

Amorós, M. (2003). La revolución traicionada. La verdadera historia de Balius y Los Amigos de Durruti. Barcelona: Virus.

Anarchist Federation (2014). Anarchist Federation Statement on Rojava. Anarchjist Federation 1 December 2014. Retrieved from https://afed.org.uk/anarchistfederation-statement-on-rojava/

Ansell, C. (2012). What is a Democratic Experiment. Contemporary Pragmatism, 9(2), 159-180.

Bakunin, M. (1953). The Political Philosophy of Bakunin: Scientific Anarchism (G. P. Maximoff Ed.). London: Free Press.

Bakunin, M. (1972). Bakunin on Anarchy. Seleccted Works by the Activist-Founder of World Anarchism (S. Dolgoff Ed.). New York: Vintage.

Bakunin, M. (1984). Marxism, Freedom and the State. London: Freedom.

Bernstein, E. (1961). Evolutionary Socialism. A Criticism and Affirmation. London: Random House.

Bogad, L. (2005). Electoral guerrilla theatre. London: Routledge.

Boggs, C., (1977a). Marxism, Prefigurative Communism, and the Problem of Workers' Control. Radical America, 11, 99-122. 
Boggs, C., (1977b). Revolutionary process, Political strategy and the Dilemma of Power. Theory and Society 4(3), 359-93.

Bookchin, M. (1995). From Urbanization to Cities: Toward a New Politics of Citizenship. New York: Cassell.

Bookchin, M. \& Biehl, J. (2009). Las políticas de la ecología social. Municipalismo libertario. Barcelona: Virus.

Bookchin, M. (2015). The Next Revolution. Popular Assemblies and the Promise of Direct Democracy. London: Verso.

Bray, M. (Forthcoming 2017). Horizontalism. In N. Jun, L. Williams and B. Franks (Eds.), Anarchism: A Conceptual Approach. London: Routledge.

Castañeda, E. (2012). The Indignados of Spain: A Precedent to Occupy Wall Street. Social Movement Studies, 11(3-4): 309-319.

Cappelletti, A. (2006). La ideología anarquista. Buenos Aires: Araucaria.

Clark, J. P. (2013). The Impossible Community. London: Bloomsbury.

Collier G. A. \& Lowery Quaratiello, E. (2005). Basta!: Land And The Zapatista Rebellion In Chiapas. Oakland: Food First Books.

Colombo, E. (2014). El espacio político de la anarquía. Esbozos para una filosofía política del Anarquismo. Madrid: Klinamen-GLAD.

Colson, D. (2001). Petit lexique philosophique de l'anarchisme. De Proudhon a Deleuze. Paris: Le Livre de Poche.

Corsín, A. \& Estalella A. (2013). The atmospheric person Value, experiment, and “making neighbors" in Madrid's popular assemblies. Journal of Ethnographic Theory 3(2), 119-139.

Crouch, C. (2004). Post-democracy. Cambridge: Polity Press

Dewey, J. (1954). The Public and its Problems. Denver: Alan Swallow.

Dickens, P. (2015). Voter apathy isn't the problem. Libcom, Retrieved from:https://libcom.org/blog/voter-apathy-isnt-problem-28022015

Estalella, A. \& Corsín, A. (2013). Asambleas populares: el ritmo urbano de una política de la experimentación. Retrieved from: http://digital.csic.es/bitstream/10261/85040/1/asambleas\%20ritmo\%20urbano\% 202013.pdf 
Fieschi, C. \& Heywood, P. (2004). Trust, cynicism and populist anti-politics. Journal of Political Ideologies, 9:3: 289-309.

Flesher Fominaya, C. (2014). Debunking Spontaneity: Spain's 15-M/Indignados as Autonomous Movement. Social Movement Studies. 14 (2), 142-163.

Flesher Fominaya, C. (2014a). Social Movements and Globalization. How Protest, Occupations and Uprising are Changing the World. New York: Palgrave.

Freeden, M. (2006). Ideologies and Political Theory: A Conceptual Approach. Oxford: Clarendon Press.

Galais, C. (2014). Don't Vote for Them: The Effects of the Spanish Indignant Movement on Attitudes about Voting. Journal of Elections, Public Opinion and Parties, 24(3), 334-350.

García Calvo, A. (1977). Qué es el Estado. Madrid: La Gaya Ciencia.

Giddens, A. (2009). The Politics of Climate Change. London: Polity.

Goldman, E. (1969). Woman Suffrage. In W. Jonson (Ed.), Anarchism and Other Essays. New York: Dover.

Graeber, D. (2001). The New Anarchists. New Left Review, 5, 61-73.

Graeber, D. (2009). Direct action: an ethnography. Oakland: AK.

Graeber, D. (2011). Occupy Wall Street's anarchist roots, Opinion-Al Jazeera English. Retrieved from: http://www.aljazeera.com/indepth/opinion/2011/11/2011112872835904508.html

Graeber, D. (2013). The Democracy Project: A history, a crisis a movement. London: Allen lane.

Grupos Anarquistas Coordinados (2013). Contra la democracia. Retrieved from: https://es-contrainfo.espivblogs.net/files/2014/07/contra-lademocracia.pdfhttps://es-contrainfo.espivblogs.net/files/2014/07/contra-lademocracia.pdf

Guérin, D. (1970). Anarchism: From Theory to Practice. New York: Monthly Review Press.

Hay, C. (2007). Why We Hate Politics. Cambridge: Polity.

Ibáñez, T. (2014). Anarquismo es movimiento. Anarquismo, neoanarquismo y postanarquismo. Barcelona: Virus. 
Jeppesen, S. (2010). Creating Guerrilla Texts in Rhizomatic Value-Practices on the Sliding Scale of Autonomy: Toward an Anti-Authoritarian Cultural Logic. In N. Jun, and S. Wahl, S. (Eds.), New Perspectives on Anarchism (pp. 473-496). Plymouth: Lexington Books.

Juris, J. (2008). Networking Futures: The Movements Against Corporate Globalization. Duke University Press.

Kaldor, M \& Selchow, S. (2013). The Bubbling Up of Subterranean Politics in Europe. Journal of Civil Society, 9(1), 78-99.

Kropotkin, A. (1987). The State: Its Historic Role. Trans. Vernon Richards. London: Freedom Press.

Kioupkiolis, A. (2016). Podemos: the ambiguous promises of left-wing populism in contemporary Spain, Journal of Political Ideologies, 21(2), 99-120 .

Kuhn, G. (2009). Anarchism, postmodernity and poststructuralism. In R. Amster, A. De Leon, Luis A. Fernandez, A. J. Nocella II and D. Shannon (Eds.), Contemporary Anarchist Studies: An Introductory Anthology of Anarchy in the Academy (pp. 18-25). London: Routledge.

Lyotard, J. F. (1984). The Postmodern Condition: A Report on Knowledge. Manchester: Manchester University Press.

Marzolf, H. \& Ganuza, E. (2016). ¿Enemigos o colegas? El 15M y la hipótesis Podemos. EMPIRIA, 33, 89-110.

Malatesta, E. (1974). Anarchy. London: Freedom Press.

Malatesta, E. (1984). Life and ideas (V. Richards Ed.). London: Freedom

Micó, J. L., \& Casero-Ripollés, A. (2014). Political activism online: Organization and media relations in the case of $15 \mathrm{M}$ in Spain. Information, Communication and Society, $17(7), 858-871$.

Monterde, A., Calleja-López, A., Aguilera, M., Barandiaran, X., \& Postill, J. (2015). Multitudinous identities: A qualitative and network analysis of the $15 \mathrm{M}$ collective identity. Information, Communication \& Society. 18(8), 930-950.

Nettlau, M. (1980). Geschichte der Anarchie. Anarchisten und Sozialrevolutionäre: die historische Entwicklung des Anarchismus in den Jahren 1880-1886 (vol. 3). Berlin: Impuls Verlag.

Observatorio Metropolitano (2014). La apuesta municipalista. La apuesta empieza por lo cercano. Madrid: Traficantes de sueños. 


\section{Versió pre-print}

Orriols, L. \& Cordero, G. (2016). The Breakdown of the Spanish Two-Party System: The Upsurge of Podemos and Ciudadanos in the 2015 General Election. South European Society and Politics. Online first: 1-24.

Postill, J. (2013). Democracy in an Age of Viral Reality: A Media Epidemiography of Spain's Indignados Movement. Ethnography, 23, 1-19.

Powell, G.B.J., Dalton, R.J. and Strøm, K.J. (2011). Comparative Politics Today: A Theoretical Framework (6th Edition). New York: Pearson.

Prieto, H. M. (1966). Posibilismo libertario. Choisy-le-Roi: Imp. des Gondoles.

Proudhon, P.-J. (1851). Idée générale de la Révolution au XIX siècle. In C. Bouglé and H. Moysset (Eds.), CEuvres complètes de P.-J. Proudhon II. Paris: Marcel Rivière.

Proudhon, P.-J. (2011). Escritos federalistas. Madrid: Akal.

Razsa, M. \& Kurnik, A. (2012). The Occupy Movement in Žižek's Hometown: Direct Democracy and a Politics of Becoming. American Ethnologist, 39(2), 238-258.

Rodon, T. \& Hierro, M. (2016). Podemos and Ciudadanos Shake up the Spanish Party System: The 2015 Local and Regional Elections. South European Society and Politics, 21(3), 339-357.

Romanos, E. (2016). Immigrants as brokers: dialogical diffusion from Spanish indignados to Occupy Wall Street, Social Movement Studies, 15(3), 247-262.

Tormey, S. (2015a). The end of representative politics. Cambridge: Polity.

Tormey, S (2015b). Democracy Will Never be the Same Again: $21^{\text {st }}$ Century Protest and the Transformation of Polítics. Recerca. Revista de Pensament i Anàlisi, 17, 107-128.

van Duijn, R. (1972). Message of a Wise Kabouter. London: Duckworth \& Co.

Ward, C. (1996). Anarchy in Action. London: Freedom Press.

Author 2 (2015)

Author 3 (2006)

Author 3 (2015) 